\title{
ARBUSCULAR MYCORRHIZA OF ENDEMIC AND ENDANGERED PLANTS FROM THE TATRA MTS
}

\author{
SZYMON ZUBEK ${ }^{1,2}$, KATARZYNA TURNAU $^{1}$, JANUSZ BŁASZKOWSKI ${ }^{3}$ \\ ${ }^{1}$ Institute of Environmental Sciences, Jagiellonian University \\ Gronostajowa 7, 30-387 Kraków, Poland \\ 2 Department of Pharmaceutical Botany, Faculty of Pharmacy \\ Jagiellonian University Collegium Medicum \\ Medyczna 9, 30-688 Kraków, Poland \\ e-mail: zubek@cm-uj.krakow.pl \\ ${ }^{3}$ Department of Plant Pathology, University of Agriculture \\ Słowackiego 17, 71-434, Szczecin, Poland
}

(Received: July 12, 2007. Accepted: August 2, 2007)

\begin{abstract}
The mycorrhizal status of 24 plant species considered as endemic, endangered in Poland and included in the IUCN Red List of Threatened Plants is reported. Selected plants and rhizosphere soil samples were collected in the Tatra Mts (Western Carpathians). Individuals of seriously threatened taxa were obtained from seeds and inoculated with available AM fungal strains under laboratory conditions. AM colonisation was found in 16 plants; 9 species were of the Arum-type, 4 - Paris and 3 taxa revealed intermediate morphology. The mycelium of the fine endophyte (Glomus tenue) and dark septate fungi (DSE) were observed in the material collected in the field. 20 AMF species (Glomeromycota) found in the rhizosphere of the investigated plants were reported for the first time from the Tatra Mts. The results provide information that might be useful for conservation and restoration programmes of these species. Application of AMF in active plant protection projects is discussed.
\end{abstract}

KEY WORDS: arbuscular mycorrhiza (AM), Arum/Paris-type, DSE, endemic and endangered plants, conservation.

\section{INTRODUCTION}

A great climatic diversity, varied topography, geological formations and soils resulted in the exeptional richness of the Tatras flora. The massif is an endemism center in Europe and the only locality for many plant species (Mirek 1996; Piękoś-Mirkowa et al. 1996). A wide range of natural processes and human activity have had a strong impact on the stability of this high-mountain ecosystem, leading to the destruction of plants' habitats, plant endangerment or even extinction. The preservation of rare and endangered species is the main goal of numerous plant protection projects and is considered as an obligation for a number of countries bound by international agreements (Kaźmierczakowa and Zarzycki 2001). There is an urgent need for interdisciplinary studies on plants of special concern to develop effective methods of their maintenance and propagation. As part of these efforts to better understand the biology and ecology of these species and to improve success of plant conservation actions, we examined the mycorrhizal status of endemics, taxa endangered in Poland and included in the IUCN Red List of Threatened Plants. We also isolated and identified AMF species occurring in the rhizosphere of the investigated taxa. Such research is considered a pre-requisite for making further active plant conservation projects successful (Turnau and Haselwandter 2002; Fuchs and Haselwandter 2004).

Most valuable taxa occurring in the Tatra Mts have been investigated mainly on floristic and phytosociological aspects (Piękoś-Mirkowa and Kaczmarczyk 1990a, b; Piękoś-Mirkowa et al. 1996). However, almost no mycorrhizal investigations have been conducted. First studies concerning mycorrhizae of plants from this mountain range had been carried out in the 1950s by a group of Polish mycologists (Nespiak 1953; Dominik and Nespiak 1954; Dominik et al. 1954a, b; Dominik and Pachlewski 1956). These studies, however, did not include most species presently considered as rare, endemic and threatened. Apart from these investigations, only selected Tatra species cultivated ex situ in the Mountain Botanic Garden in Zakopane have been surveyed (Zubek et al. 2005). Except for the above mentioned studies conducted over 50 years ago, no mycorrhizal assessment of the Tatra endemic and endangered plants have been carried out in the field. 


\section{MATERIALS AND METHODS}

\section{Site description and field sampling}

The material was collected from selected locations in the Polish Tatra Mts (Western Carpathians). The sampling sites and the number of plant specimens were strictly determined in order not to cause additional threat to the taxa. The special permission for rare and endangered plant species collection was obtained from the authorities of the Tatra National Park (TPN). On the whole, 17 taxa were collected in the field during the flowering and early seed formation period (June and July in the 2003). Root systems with soil were carefully excavated intact and transported in plastic bags to the laboratory. Site numbers, plant species collected and the locations of sampling are as follows: $\mathbf{1}$. Cardaminopsis neglecta, above Czarny Staw Gąsienicowy lake, $1730 \mathrm{~m}$ a.s.1., 49'13'33' N, 2001'36' E; 2. Cortusa matthioli, Dolina Małej Łąki valley, 990 m a.s.1., $49^{\circ} 16^{\prime} 20^{\prime}$ 'N, 1954'09' $\mathrm{E}$; 3. Leucanthemum waldsteinii, Dolina Ku Dziurze valley, $1100 \mathrm{~m}$ a.s.1., 49¹6'09' 'N, 1956'38' 'E; 4. Melampyrum herbichii, Dolina Ku Dziurze valley, $1100 \mathrm{~m}$ a.s.1., 49 $16^{\prime} 09^{\prime}$ 'N, 19'56'38' 'E; 5. Ranunculus pseudomontanus, above Czarny Staw Gąsienicowy lake, $1630 \mathrm{~m}$ a.s.1., 49 $133^{\prime} 42^{\prime}$ 'N, 20 01'25' 'E; 6. Knautia kitaibeli, Wąwóz Kraków ravine, 1115 m a.s.1., 49 14 '13' 'N, 1952'28' 'E; 7. Knautia kitaibeli, Wąwóz Kraków ravine, $1115 \mathrm{~m}$ a.s.1., 49 $14^{\prime} 17^{\prime}{ }^{\prime} \mathrm{N}, 19^{\circ} 52^{\prime} 12^{\prime}{ }^{\prime} \mathrm{E}$; 8. Delphinium oxysepalum, Dolina Mułowa valley, 1830 m a.s.1., 49 $14^{\prime} 19^{\prime}$ 'N, 1954'14' 'E; 9. Soldanella carpatica, Saxifraga wahlenbergii, Dolina Litworowa valley, 1845 m a.s.1., 49 $14^{\prime} 19^{\prime}$ 'N, $19^{\circ} 54^{\prime} 57^{\prime}$ 'E; 10. Soldanella carpatica, Saxifraga wahlenbergii, Mała Dolinka valley, 1275 $\mathrm{m}$ a.s.1., 49 $15^{\prime} 19^{\prime}$ 'N, $19^{\circ} 56^{\prime} 00^{\prime}$ 'E; 11. Sesleria tatrae, Piec rock in Czerwone Wierchy massif, $1485 \mathrm{~m}$ a.s.1., $49^{\circ} 14^{\prime} 53^{\prime}$ 'N, $19^{\circ} 53^{\prime} 21^{\prime}$ 'E; 12. Campanula polymorpha, Cerastium tatrae, Ciemniak Mt., $1950 \mathrm{~m}$ a.s.1., 49 13 '57' 'N, 1954'00' 'E; 13. Dianthus plumarius subsp. praecox, Thymus pulcherrimus, Euphrasia tatrae, Sarnia Skała rock, $1300 \mathrm{~m}$ a.s.1., 49¹5'12'’N, 1956'30' 'E.

\section{Plant inoculation under laboratory conditions}

Field collection of 7 plant species were impossible due to the rarity of the taxa. Hence the mycorrhizal status of Artemisia eriantha, Astragalus penduliflorus, Papaver burseri, Pulsatilla slavica, Saussurea pygmaea, Senecio umbrosus and Sibbaldia procumbens have been surveyed under laboratory conditions. Seeds of these plants were provided by the Mountain Botanic Garden of the Polish Academy of Sciences in Zakopane or collected in the Tatras. The seedlings were obtained on Petri dishes according to available protocols (Piękoś-Mirkowa and Kaczmarczyk 1990a, b). The 4-6 day-old seedlings of each taxa were put in two pots $(700 \mathrm{ml})$ on sterile substrata (A, B) that were inoculated. The substrata, whose characteristics are reported in Table 1, were provided by the Botanic Garden of the Jagiellonian University. S. pygmaea seedlings were cultivated on the substratum B, the other species on the substratum A (with an addition of ground limestone). The mixture of available AMF species was used as inoculum; Glomus claroideum BEG96, Glomus constrictum 262-5 (6) (the collection of C. Walker), Glomus geosporum 25-4 (the collection of C. Walker), Glomus intraradices E-1-99, BIORIZE Sarl France, Glomus mosseae BEG12, Glomus mosseae BEG. The cultures were grown for two months under greenhouse conditions and then roots were collected and stained in the same way as the material collected in the field.

\section{Mycorrhizal status assessment}

In total, roots of 24 plant species were analysed. Only roots attached to the main root of the plants were used for mycorrhizal assessment (to avoid the possibility of collecting roots from another species). The roots were prepared according to the modified Phillips and Hayman (1970) method. After careful washing in running tap water, the roots were cleared in $10 \% \mathrm{KOH}$ for 24 hours and subsequently rinsed in water. The material was acidified in $5 \%$ lactic acid in water for $24 \mathrm{~h}$, then stained with $0.01 \%$ aniline blue in $80 \%$ lactic acid for $24 \mathrm{~h}$, and finally stored in $80 \%$ lactic acid. The whole procedure was carried out at room temperature. Mycorrhizal colonisation analysis were conducted accorrding to Trouvelot method (Trouvelot et al. 1986). The morphology of AM colonisation, the presence of AM structures (arbuscules, vesicles, coils), and the occurrence of other root endophytes, such as dark septate fungi (DSE) and fungi from the genus Olpidium were assessed using the light microscope Nikon Eclipse 800 with Nomarski interference contrast optics. Roots were also analysed for the presence of the fine endophyte [Glomus tenue (Greenall) I.R. Hall; Thippayarugs et al. 1999; Dodd et al. 2000], as the fungus has been observed to dominate in some alpine habitats (Haselwandter and Read 1980).

\section{AMF spores isolation and identification}

Soil samples were excavated in 13 selected locations in the Tatra Mts, from which the plant material was obtained. Additional soil samples were collected from the natural stands of two seriously endangered plants of special concern, which were cultivated to assess their mycorrhizal status under laboratory conditions. In case of Pulsatilla slavi$c a$, soil samples were obtained from the immediate vicinity (within $20 \mathrm{~cm}$ ) of the individuals occurring in a natural population. As Senecio umbrosus is considered extinct in the wild in Poland, sampling procedure was carried out in the stand where the species used to grow in the Tatras. The site numbers and the locations of sampling are as follows: 14. S. umbrosus, Szeroki Żleb gully in Chochołowska valley, 1130 m a.s.1., $49^{\circ} 15^{\prime} 06^{\prime}{ }^{\prime} \mathrm{N}, 19^{\circ} 48^{\prime} 12^{\prime}{ }^{\prime} \mathrm{E} ; 15$. $P$. slavica, Koryciska Wielkie ravine, $1130 \mathrm{~m}$ a.s.1., $49^{\circ} 16^{\prime} 12^{\prime}{ }^{\prime} \mathrm{N}$,

TABLE 1. The chemical properties of substrata used in the mycorrhizal status survey under laboratory conditions (see Materials and Methods).

\begin{tabular}{|c|c|c|c|c|c|c|c|c|c|c|c|c|c|}
\hline \multirow{2}{*}{ Substrata } & \multirow{2}{*}{$\begin{array}{c}\mathrm{pH} \\
\left(\mathrm{H}_{2} \mathrm{O}\right)\end{array}$} & \multirow{2}{*}{$\mathrm{N} \%$} & \multirow{2}{*}{$\mathrm{C} \%$} & \multirow{2}{*}{$\begin{array}{l}\text { Organic } \\
\text { matter } \%\end{array}$} & \multirow{2}{*}{$\mathrm{C} / \mathrm{N}$} & \multicolumn{4}{|c|}{$\begin{array}{c}\text { Contents total } \\
\text { in } \mathrm{mg} 100 \mathrm{~g}^{-1} \text { of dry soil }\end{array}$} & \multicolumn{4}{|c|}{$\begin{array}{l}\text { Exchangeable cations } \\
\text { in } \mathrm{mg} 100 \mathrm{~g}^{-1} \text { of dry soil }\end{array}$} \\
\hline & & & & & & $\mathrm{K}_{2} \mathrm{O}$ & $\mathrm{P}_{2} \mathrm{O}_{5}$ & $\mathrm{MgO}$ & $\mathrm{CaO}$ & $\mathrm{K}$ & $\mathrm{Na}$ & $\mathrm{Mg}$ & $\mathrm{Ca}$ \\
\hline A & 6.79 & 0.43 & 5.53 & 9.88 & 13.40 & 70.40 & 12.20 & $>20.00$ & 960.00 & 70.00 & 4.80 & 16.75 & 690.00 \\
\hline B & 6.78 & 0.18 & 4.79 & 7.70 & 24.50 & 6.60 & 1.00 & 18.00 & 490.00 & 5.00 & 2.40 & 15.75 & 350.00 \\
\hline
\end{tabular}


$19^{\circ} 48^{\prime} 27^{\prime}$ 'E. In total, 15 trap cultures were established with the soil samples collected from the rhizosphere of the investigated plants. The soil with root fragments were placed in pots $(500 \mathrm{ml})$ containing sterile substratum (sand: expanded clay 2:1, v/v). The cultures were kept in Sigma sunbags (B7026) under greenhouse conditions using Plantago lanceolata L. as a host plant (approximately 20 seedlings per pot). After six months spores were isolated using the wet filtering technique (mesh size $50 \mu \mathrm{m}$ ). Morphological properties of spores and their subcellular structures were determined in material mounted in a drop of polyvinyl alcohol/lactic acid/glycerol (PVLG) and in a mixture of PVLG/Melzer's reagent $(4: 1, \mathrm{v} / \mathrm{v})$ on a slide (Omar et al. 1979). Slides with isolated spores were deposited in the slide collection of the Department of Plant Pathology, University of Agriculture, Szczecin. Cultures of selected AMF strains are kept under greenhouse conditions in the collections of the Jagiellonian University in Kraków and the University of Agriculture in Szczecin.

\section{RESULTS}

\section{AM status and morphology}

Arbuscular mycorrhizae with arbuscules, which are the structural and functional criterion of the symbiosis, were observed in 16 of the 24 species examined (67\%) (Table 2). In roots of these plants coarse AMF (mycelium diameter above $2 \mu \mathrm{m})$ dominated. The fine endophyte, usually considered Glomus tenue, characterised by mycelium ca. $1 \mu \mathrm{m}$ diameter, abundant small vesicles or swellings of a diameter vary-

TABLE 2. Mycorrhizal status of endemic and threatened plants of the Tatra Mts.

\begin{tabular}{|c|c|c|c|c|c|c|c|c|c|c|}
\hline \multirow[t]{2}{*}{ Family } & \multirow{2}{*}{ Plant species a } & \multirow{2}{*}{$\begin{array}{l}\text { Category } \\
\text { of threat }{ }^{b}\end{array}$} & \multirow{2}{*}{$\begin{array}{c}\text { AM } \\
\text { literature } \\
\text { status c }^{c}\end{array}$} & \multirow{2}{*}{$\begin{array}{l}\text { Number } \\
\text { of plants } \\
\text { analysed }\end{array}$} & \multirow{2}{*}{$\begin{array}{l}\text { AM } \\
\text { type }^{d}\end{array}$} & \multicolumn{3}{|c|}{ AM structures ${ }^{\mathrm{e}}$} & \multicolumn{2}{|c|}{$\begin{array}{c}\text { Other } \\
\text { endophytes f }\end{array}$} \\
\hline & & & & & & $\mathrm{C}$ & $\mathrm{V}$ & $\mathrm{FE}$ & DSE & Olp. \\
\hline \multirow[t]{4}{*}{ Asteraceae } & * Artemisia eriantha Ten. & LR & $3-$ & 5 & A & - & + & $\times$ & $\times$ & $\times$ \\
\hline & Leucanthemum waldsteinii (Sch. Bip.) Pouzar & P-se & $2+, 3+$ & 5 & A & + & + & + & + & - \\
\hline & * Saussurea pygmaea (Jacq.) Spreng. & $\mathrm{CR}$ & $2+$ & 10 & A & - & - & $x$ & $x$ & $x$ \\
\hline & * Senecio umbrosus Waldst. et Kit. & EW & NS & 10 & A & - & + & $x$ & $\times$ & $x$ \\
\hline \multirow[t]{2}{*}{ Brassicaceae } & Cardaminopsis neglecta (Schult.) Hayek & P-se & $2-$ & 3 & - & - & - & - & - & - \\
\hline & Dentaria glandulosa Waldst. \& Kit. & P-se & $3-$ & 5 & - & - & - & - & - & - \\
\hline Campanulaceae & Campanula polymorpha Witasek & P-se & $3+$ & 8 & A & + & + & + & + & - \\
\hline \multirow[t]{2}{*}{ Caryophyllaceae } & Cerastium tatrae Borbás & W-e & $3-$ & 9 & - & - & - & - & + & - \\
\hline & Dianthus plumarius L. subsp. praecox (Kit.) Pawł. & W-e, prot. & $2-, 3-$ & 5 & - & - & - & - & + & - \\
\hline Dipsacaceae & Knautia kitaibelii (Schult.) Borbás & W-se & $2+$ & 3 & A & + & + & - & + & + \\
\hline Fabaceae & * Astragalus penduliflorus Lam. & $\mathrm{CR}$ & NS & 10 & A & - & - & $x$ & $\times$ & $\times$ \\
\hline Lamiaceae & Thymus pulcherrimus Schur & $\mathrm{P}-\mathrm{e}$ & $3+$ & 9 & A & + & + & + & + & - \\
\hline Papaveraceae & * Papaver burseri Crantz & T-se & $2-$ & 15 & - & - & - & $\times$ & $\times$ & $x$ \\
\hline \multirow[t]{2}{*}{ Poaceae } & Festuca versicolor Tausch subsp. versicolor & P-se & $2+$ & 11 & $\mathrm{P}$ & + & + & + & + & + \\
\hline & Sesleria tatrae (Degen) Deyl & W-e & $3+$ & 10 & $\mathrm{P}$ & + & + & - & + & - \\
\hline \multirow[t]{2}{*}{ Primulaceae } & Cortusa matthioli $\mathrm{L}$ & LR, prot. & $2+$ & 5 & $\mathrm{P}$ & + & - & - & + & - \\
\hline & Soldanella carpatica Vierh. & W-e & $2+, 3+$ & 5 & $\mathrm{P}$ & + & - & + & + & - \\
\hline \multirow[t]{3}{*}{ Ranunculaceae } & Delphinium oxysepalum Borbás \& Pax & W-e & NS & 3 & I & + & + & - & - & - \\
\hline & * Pulsatilla slavica $\mathrm{G}$. Reuss & $\begin{array}{c}\text { VU, } \\
\text { IUCN, } \\
\text { W-e, prot., } \\
\text { CEWH }\end{array}$ & NS & 10 & $\mathrm{I}$ & - & - & $x$ & $\times$ & $x$ \\
\hline & Ranunculus pseudomontanus Schur & P-se & $2+$ & 5 & $\mathrm{I}$ & + & + & + & + & - \\
\hline Rosaceae & * Sibbaldia procumbens L. & VU & $1-, 4+$ & 10 & A & - & + & $x$ & $x$ & $x$ \\
\hline Saxifragaceae & Saxifraga wahlenbergii Ball & W-e & NS & 6 & - & - & - & - & - & - \\
\hline \multirow[t]{2}{*}{ Scrophulariaceae } & Euphrasia tatrae Wettst. & P-se & NS & 6 & - & - & - & - & + & - \\
\hline & Melampyrum herbichii Woł. & P-se & NS & 5 & - & - & - & - & + & - \\
\hline
\end{tabular}

\footnotetext{
a Names of plants after Mirek Z., Piękoś-Mirkowa H., Zając A., Zając M. (2002) Flowering plants and pteridophytes of Poland. A Checklist. Asterix (*) indicates that the mycorrhizal status of species was analysed under laboratory conditions.

b Category of threat to the taxon in Poland and on a global scale after Kaźmierczakowa R., Zarzycki K. (2001) Polish Red Data Book of Plants: LR lower risk, CR - critically endangered, EW - extinct in the wild, VU - vulnerable, IUCN - species included in the world list of threatened plant species, $\mathrm{CEWH}$ - protection provided by the Convention on the Conservation of European Wildlife and Natural Habitats. The legal status of the taxon in Poland after Piękoś-Mirkowa H., Mirek Z. (2003) Flora Polski. Atlas roślin chronionych: prot. - protected plant species. Endemism of the species after PiękośMirkowa H., Mirek Z., Miechówka A. (1996) Pol. Bot. Stud. 12: 1-107: P-e - Pan-Carpathian endemic species, W-e - West-Carpathian endemic species, P-se - Pan-Carpathian subendemic species, W-se - West-Carpathian subendemic species, T-se - Tatra subendemic species.

${ }^{c}$ AM status according to available literature: 1 - Harley J.L., Harley E.L. (1987a) N. Phytol. (Suppl.) 105: 1-102, Harley J.L., Harley E.L. (1987b) N. Phytol. 107: 741-749; 2 - Nespiak A. (1953) Acta Soc. Bot. Pol. 22: 97-125; Dominik T., Nespiak A. (1954) Acta. Soc. Bot. Pol. 22: 753-769; Dominik T., Nespiak A., Pachlewski R. (1954a) Acta Soc. Bot. Pol. 23: 487-504; Dominik T., Nespiak A., Pachlewski R. (1954b) Acta Soc. Bot. Pol. 23: 471-485; Dominik T., Pachlewski R. (1956) Acta Soc. Bot. Pol. 25: 3-26; 3 - Zubek S., Turnau K., Błaszkowski J. (2005) Acta Mycol. 40 (1): 25-41; 4 - Wang B., Qiu Y.L. (2006) Mycorrhiza 16: 299-363; (+) AM present, (-) AM absent, NS - not surveyed.

d AM status and morphotype observed in this study: A - Arum type, P - Paris type, I - intermediate type.

e AM structures: C - coils, V - vesicles, FE - Fine endophyte mycelium; (+) present, (-) absent.

f Other endophytes: DSE - mycelium of dark septate endophytes; Olp. - resting spores of Olpidium spp.; (+) present, (-) absent, (×) - not surveyed because the plants were obtained from seeds under laboratory conditons.
} 

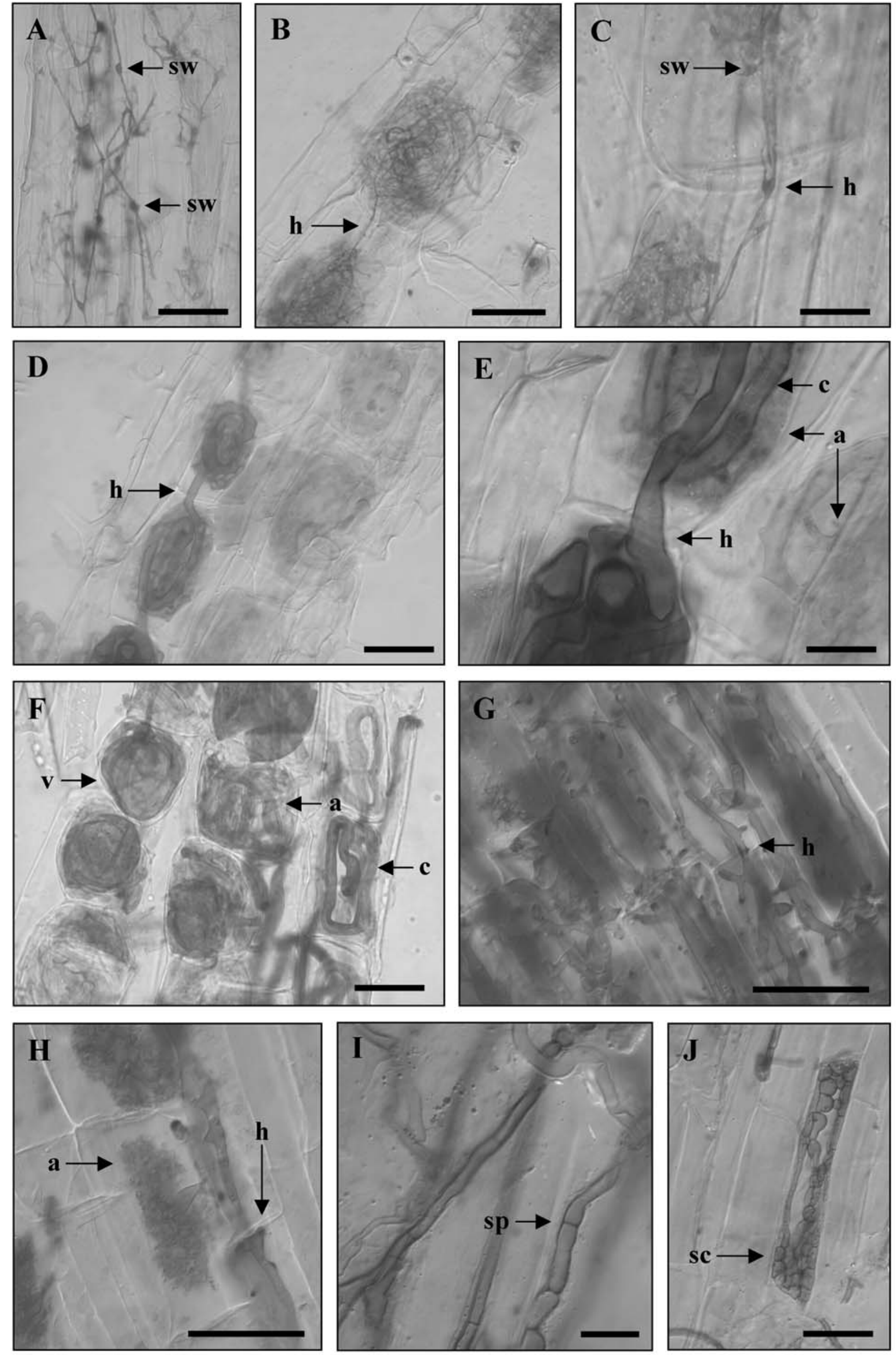
TABLE 3. AMF species (Glomeromycota) associated with the investigated plants in the Tatra Mts.

\begin{tabular}{|c|c|}
\hline Family & Fungal species ${ }^{a}$ \\
\hline Archaeosporaceae & $\begin{array}{l}\text { Archaeospora gerdemannii (S.L. Rose, B.A. Daniels \& Trappe) J.B. Morton \& D. Redecker 1, 3,4,6,12,15 } \\
\text { Arch. trappei (R.N. Ames \& Linderman) J.B. Morton \& D. Redecker }{ }^{1,15}\end{array}$ \\
\hline Acaulosporaceae & 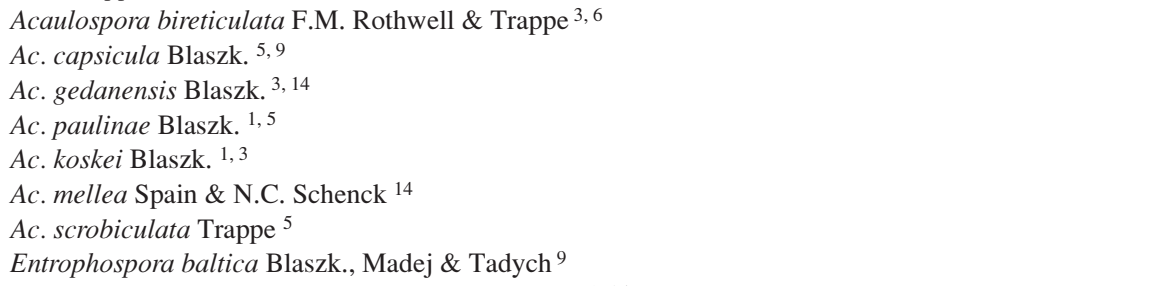 \\
\hline Gigasporaceae & Scutellospora dipurpurescens J.B. Morton \& Koske 2,15 \\
\hline Pacisporaceae & Pacispora scintillans (S.L. Rose \& Trappe) Sieverd. \& Oehl 12, 13 \\
\hline Glomeraceae & $\begin{array}{l}\text { Glomus aggregatum N.C. Schenck \& S.M. Sm. emend. Koske }{ }^{7} \\
\text { G. caledonium (Nicol. \& Gerd.) Trappe \& Gerd. }{ }^{15} \\
\text { G. claroideum N.C. Schenck \& S.M. Sm. }{ }^{7-11,14} \\
\text { G. constrictum Trappe }{ }^{1-11,13-15} \\
\text { G. deserticola Trappe, Bloss \& J.A. Menge }{ }^{6,15} \\
\text { G. fasciculatum (Thaxt.) Gerd. \& Trappe emend. C. Walker \& Koske }{ }^{6,7,13} \\
\text { G. geosporum (Nicol. \& Gerd.) C. Walker }{ }^{6} \\
\text { G. macrocarpum Tul. \& C. Tul. }{ }^{9,15}\end{array}$ \\
\hline
\end{tabular}

a Species names after Walker C., Trappe J.M. (1993) Mycol. Res. 97: 339-344. Numbers after species names indicate site numbers (see Materials and Methods) from which the soil samples were collected

ing from 3-9 $\mu \mathrm{m}$ and fan-shaped branches (Fig. 1A), was found sporadically in 5 plants and was rarely observed to form arbuscules in these plants. The exception was Soldanella carpatica. In the root systems of this species, G. tenue was the only endophyte from Glomeromycota, and formed Paris-type colonisation (Fig. 1B-C). No AMF structures were found in roots of eight species belonging to the Brassicaceae, Caryophyllaceae, Papaveraceae, Saxifragaceae and Scrophulariaceae families.

The examined plants from the Poaceae and Primulaceae families showed Paris-type colonisation in which neighbouring cortical cells contained hyphal coils without hyphae in the intercellular spaces (Fig. 1B-F). The intermediate AM colonisation was found among representatives of the Ranunculaceae. The fungi colonised roots by growing mainly intracellularly from cell to cell, but the arbuscules were formed terminally as in the Arum-type (Fig. 1G-H). Mycorrhizal plants of the families Asteraceae, Campanulaceae, Dipsacaceae, Fabaceae, Lamiaceae and Rosaceae were of the Arum morphology (Table 2). AMF hyphae were found mainly in the intercellular spaces of the root cortex, forming arbuscules terminally, one per cortical cell.

\section{DSE}

Dark septate endophytes (DSE) were found in 13 of the 17 species collected in the field (76\%), however, the percentage of root colonisation was low. The regularly septated hyphae were accompanied sporadically by sclerotia (Fig. 1I-J). The mycelium stained with anilin blue or rema- ined brownish. DSE were observed in the cortex together with AMF, and were also detected in the roots of non-mycorrhizal species from the Caryophyllaceae and Scrophulariaceae families (Table 2). In both cases, however, they were not abundantly developed.

\section{AMF spores isolated from trap cultures}

Spores of 20 species were extracted from the trap cultures established with the soils collected from the Tatra Mts (Table 3). AMF spores were found in all pots, indicating that the propagules of Glomeromycota were present in the rhizosphere of all examined plants, including those that were found to be non-mycorrhizal in this study. Spores of Archaeospora gerdemannii, Glomus claroideum and $G$. constrictum were most frequently isolated from the pot cultures. In contrast, Acaulospora mellea, Ac. scrobiculata, Entrophospora baltica, G. aggregatum, G. caledonium and $G$. geosporum were detected in single cultures.

\section{DISCUSSION}

The use of soil microorganism consortia to support plant growth have been proposed in agriculture (Vestberg et al. 2002), horticulture (Hamel 1996), and in the restoration strategies of destroyed habitats (Leyval et al. 2002; González-Chávez et al. 2006; Turnau et al. 2006). The application of rhizosphere microbiota, especially arbuscular mycorrhizal fungi (AMF), in the conservation programmes

Fig. 1. A-J - Light micrographs of endophytes observed in the roots of rare and endangered plant species of the Tatra Mts.

A - Fine endophyte (Glomus tenue) mycelium in the cortex of Leucanthemum waldsteinii; sw - swollen hyphae, scale bar - 50 um.

B-C - G. tenue colonisation of Paris-type in the cortex cells of Soldanella carpatica; sw - swollen hypha, h - hyphae growing intracellularly from cell to cell, bars: B $-50 \mu \mathrm{m}, \mathrm{C}-40 \mu \mathrm{m}$.

D-E - Coarse AMF colonising Cortusa matthioli root (Paris-type); h - hyphae growing intracellularly, a - arbuscules formed on the coils (c), bars: D - 50 $\mu \mathrm{m}, \mathrm{E}-25 \mu \mathrm{m}$.

F - Paris-type of AM infection in the cortex of Festuca versicolor subsp. versicolor; $\mathrm{v}$ - vesicle, a - arbuscule, c - coil, bar - 50 um.

G-H - Pulsatilla slavica - AM colonisation of intermediate type; intracellular growth of hyphae (h) and terminally formed arbuscule (a), bars - 50 um.

I-J - Septate hypha (sp) and sclerotium (sc) of DSE in the cortex of Knautia kitaibelii, bars: I - $15 \mu \mathrm{m}, \mathrm{J}-50 \mu \mathrm{m}$. 
of threatened taxa has been also highlighted (Gemma et al. 2002; Turnau and Haselwandter 2002; Fisher and Jayachandran 2005). Some research clearly showed that AMF enhance nutrient uptake and growth of endangered plants (Barroetavena et al. 1998; Fisher and Jayachandran 2002; Panvar and Vyas 2002). Both in maintaining species composition and reintroduction of rare and threatened taxa, knowledge of plant interactions below ground is a necessity (Eriksen et al. 2002). In our research we recognised the mycorrhizal status of 24 plant species of a high priority, i.e. considered as endemic, listed on the Polish Red Data Book of Plants, endangered on the global scale, and protected in Poland. The present studies provide important basic information concerning the mycorrhization of valuable taxa. They enable the selection of plant species for which the use of AMF might be possible in restoration attempts. However, this research must be followed up by investigating plant-fungus interactions and possible dependency. Only on the basis of detailed research, successful methods of AMF application in conservation programmes can be developed (Fisher and Jayachandran 2005).

Two main structural classes of AM symbiosis, the Arumand Paris-type (Smith and Read 1997), were observed in roots of the investigated plants. An intermediate type was also detected among representatives of the Ranunculaceae family. It is well recognised that the AM morphology may depend both on the plant and fungal identity (Cavagnaro et al. 2001; Dickson 2004; Kubota et al. 2005). Nevertheless, some recent research indicates that the issue of AMF colonisation patterns is more complex. It has been suggested that e.g. the ecology of the plant and environmental factors may have an impact on AM morphology (Yamato 2004; Ahulu et al. 2005). Recent studies have also revealed several exceptions to the main morphological types, such as the occurrence of paired arbuscules in roots of Linum usitatissimum L. (Dickson et al. 2003) or atypical Paris morphology in the Mediterranean species Similax aspera L. (Bedini et al. 2000). Numerous intermediate structural classes of AM symbiosis have been described as well (Dickson 2004; Yamato 2004; Ahulu et al. 2005). This suggests that studies on AM morphology of species from different genera and families are needed to analyse mechanisms involved in forming particular AM colonisation types. Moreover, Smith and Smith (1997) suggested that differences in the fungal pattern of root colonisation may influence physiology of the symbiosis. Hence the information of AM morphology seems to be useful for further research concerning practical application of AMF in active plant conservation projects.

The mycelium of fine endophyte (Glomus tenue) was detected in roots of 6 plant species collected from the Tatras. However, the root length occupied by this fungus was low. Only in roots of Soldanella carpatica, where coarse AMF were not observed, the mycelium was abundant. This suggests that $G$. tenue may be the main root coloniser only when there is no competition with other Glomeromycota species. Its role might be important at higher altitudes, where coarse AMF are not present. The fungus has commonly been observed in the Alps, and has been shown to become dominant above $3000 \mathrm{~m}$ above sea level (Read and Haselwandter 1981).

20 AMF species revealed in the rhizosphere of rare and endangered plants collected from 15 locations of the Tatra
Mts were recorded for the first time in this region. Functioning soil microbiota, including AMF, is considered crucial for successful revegetation attempts (Haselwandter 1997; Turnau and Haselwandter 2002). Hence the knowledge of AM status and AM fungi occurring in rhizosphere is necessary to prepare a soil environment as natural as possible for plants to be established in introduction or reintroduction projects. AMF strains from the habitats of endangered taxa maintained in trap cultures can serve as a ready-to-use inoculum source for restoration programmes (Turnau and Haselwandter 2002; Fuchs and Haselwandter 2004).

Dark septate endophytes (DSE) are root colonisers coappearing with mycorrhizal fungi in a variety of ecosystems, especially in arctic and alpine habitats (Haselwandter and Read 1980; Read and Haselwandter 1981; Jumponen 2001). They were also found in roots of several plants surveyed in this study. However, the percentage of root length occupied by DSE mycelium was low. On the basis of our observations it is impossible to conclude on the influence of this group of endophytes on plants. In order to clarify the degree of benefit that these plant species may derive from DSE, experimental research is needed. Nevertheless, since some strains of these endophytes have been shown to form mutualistic associations (Haselwandter and Read 1982), and therefore in some cases classified as mycorrhizal (Jumponen 2001), they should not be neglected in ecological studies. Similarly to AM fungi, they may strongly improve active protection projects of rare and threatened taxa. The application of DSE could be important in case of plants which are not colonised by AMF, e.g. species from the Caryophyllaceae and Scrophulariaceae examined in this study.

\section{ACKNOWLEDGEMENTS}

The present research was financially supported by the Polish Ministry of Science and Higher Education, project no. 2 P04G 00628 (2005-2006) and DS/758/UJ. The authors are grateful to Prof. H. Piękoś-Mirkowa, M. Pacyna, M.Sc. eng. A. Delimat and M.Sc. eng. E. Walusiak (Institute of Nature Conservation of the Polish Academy of Sciences, Kraków) for their suggestions on plant species selection and for providing us with the seeds of threatened taxa. Dr. W. Bartoszek (Institute of Botany, Jagiellonian University, Kraków) is acknowledged for plant species revision. We also wish to thank the authorities of the Tatra National Park (TPN) for the permission for material collection.

\section{LITERATURE CITED}

AHULU E.M., NAKATA M., NONAKA M. 2005. Arum- and Paris-type arbuscular mycorrhizas in a mixed pine forest on sand dune soil in Niigata Prefecture, central Honshu, Japan. Mycorrhiza 15: 129-136.

BARROETAVENA C., GISLER S.D., LUOMA D.L., MEINKE R.J. 1998. Mycorrhizal status of the endangered species Astragalus applegate $i$ Peck as determined from a soil bioassay. Mycorrhiza 8: 117-119.

BEDINI S., MAREMMANI A., GIOVANNETTI M. 2000. Paris-type mycorrhizas in Smilax aspera L. growing in a Mediterranean sclerophyllous wood. Mycorrhiza 10: 9-13. 
CAVAGNARO T.R., GAO L.-L., SMITH F.A., SMITH S.E. 2001. Morphology of arbuscular mycorrhizas is influenced by fungal identity. New Phytol. 151: 469-475.

DICKSON S., SCHWEIGER P., SMITH F.A., SÖDERSTRÖM B., SMITH S. 2003. Paired arbuscules in the Arumtype arbuscular mycorrhizal symbiosis with Linum usitatissimum. Can. J. Bot. 81: 457-463.

DICKSON S. 2004. The Arum-Paris continuum of mycorrhizal symbioses. New Phytol. 163: 187-200.

DODD J.C., BODDINGTON C.L., RODRIGUEZ A., GONZÁLEZ-CHÁVEZ C., MANSUR I. 2000. Mycelium of arbuscular mycorrhizal fungi (AMF) from different genera: form, function and detection. Plant Soil 226: 131-151.

DOMINIK T., NESPIAK A. 1954. Untersuchungen über den Mykotrophisumus der Pflanzenassoziazionen im Krumholzkiefergebiet des Hohen Tatra-Gebirge. Acta Soc. Bot. Pol. 22: 753-769. (in Polish with German summary)

DOMINIK T., NESPIAK A., PACHLEWSKI R. 1954a. Untersuchungen über den Mykotrophisumus der Pflanzenassoziazionen der höchsten Teile der Fichtenwälder im Tatragebirge. Acta Soc. Bot. Pol. 23: 487-504. (in Polish with German summary)

DOMINIK T., NESPIAK A., PACHLEWSKI R. 1954b. Untersuchungen über den Mykotrophisumus der Pflanzenassoziazionen der Kalkfelsen im Tatragebirge. Acta Soc. Bot. Pol. 23: 471-485. (in Polish with German summary)

DOMINIK T., PACHLEWSKI R. 1956. Untersuchungen über den Mykotrophisumus der Pflanzenassoziazionen der unteren Waldstufe im Tatragebirge. Acta Soc. Bot. Pol. 25: 3-26. (in Polish with German summary)

ERIKSEN M., BJUREKE K.E., DHILLION S.S. 2002. Mycorrhizal plants of traditionally managed boreal grasslands in Norway. Mycorrhiza 12: 117-123.

FISHER J.B., JAYACHANDRAN K. 2002. Arbuscular mycorrhizal fungi enhance seedling growth in two endangered plant species from south Florida. Int. J. Plant Sci. 163 (4): 559-566.

FISHER J.B., JAYACHANDRAN K. 2005. Presence of arbuscular mycorrhizal fungi in South Florida native plants. Mycorrhiza 15: 580-588.

FUCHS B., HASELWANDTER K. 2004. Red list plants: colonization by arbuscular mycorrhizal fungi and dark septate endophytes. Mycorrhiza 14: 277-281.

GEMMA J.N., KOSKE R.E., HABTE M. 2002. Mycorrhizal dependency of some endemic and endangered Hawaiian plant species. Am. J. Bot. 89 (2): 337-345.

GONZÁLEZ-CHÁVEZ M.C., VANGRONSVELD J., COLPAERT J., LEYVAL C. 2006. AMF and heavy metals: tolerance mechanisms and potential use in bioremediation. In: Trace elements in the environment. Biogeochemistry, biotechnology, and bioremediation. Prasad M.N.V., Sajwan K.S., Naidu R. (eds). CRC Taylor \& Francis, Boca Raton, London, New York, pp. 211-234.

HAMEL C. 1996. Prospects and problems pertaining to the management of arbuscular mycorrhizae in agriculture. Agr. Ecosyst. Environ. 60: 197-210.

HASELWANDTER K., READ D.J. 1980. Fungal associations of roots of dominant and sub-dominant plants in high-alpine vegetation systems with special reference to mycorrhiza. Oecologia 45: 57-62.

HASELWANDTER K., READ D.J. 1982. The significance of a root-fungus association in two Carex species of high-alpine plant communities. Oecologia 53: 352-354.

HASELWANDTER K. 1997. Soil micro-organisms, mycorrhiza, and restoration ecology. In: Restoration ecology and sustainable development. Urbańska K.M., Webb N.R., Edwards P.J. (eds). Cambridge University Press, Cambridge, pp. 65-80.

JUMPPONEN A. 2001. Dark septated endophytes - are they mycorrhizal? Mycorrhiza 11: 207-211.

KAŹMIERCZAKOWA R., ZARZYCKI K. (eds) 2001. Polish Red Data Book of Plants. W. Szafer Institute of Botany, Insti- tute of Nature Conservation, Polish Academy of Sciences, Kraków. (in Polish with English summmary)

KUBOTA M., MCGONIGLE T.P., HYAKUMACHI M. 2005. Co-occurrence of Arum- and Paris-type morphologies of arbuscular mycorrhizae in cucumber and tomato. Mycorrhiza 15: 73-77.

LEYVAL C., JONER E.J., DEL VAL C., HASELWANDTER K. 2002. Potential of arbuscular mycorrhizal fungi for bioremediation. In: Mycorrhizal technology in agriculture. From genes to mycorrhiza application. Gianinazzi S., Schüepp H., Barea J.M., Haselwandter K. (eds). Birkhauser Verlag/Switzerland, pp. $175-186$

MIREK Z. (ed.) 1996. Nature of the Tatra National Park. Tatra National Park, W. Szafer Institute of Botany, Institute of Nature Conservation, Polish Academy of Sciences, Kraków-Zakopane.

NESPIAK A. 1953. Mycotrophy of the alpine vegetation of the Tatra Mts. Acta Soc. Bot. Pol. 22: 97-125. (in Polish with English summary)

OMAR M.B., BOLLAND L., HEATHER W.A. 1979. A permanent mounting medium for fungi. B. Br. Mycol. Soc. 13: 13$-32$.

PANWAR J., VYAS A. 2002. AM fungi: A biological approach towards conservation of endangered plants in Thar desert, India. Curr. Sci. India 82 (5): 576-578.

PHILLIPS J., HAYMAN D.S. 1970. Improved procedures for clearing roots and staining parasitic and vesicular-arbuscular mycorrhizal fungi for rapid assessment of infection. T. Br. Mycol. Soc. 55: 158-161.

PIĘKOŚ-MIRKOWA H., KACZMARCZYK D. 1990a. Pulsatilla slavica Reuss - ecology, threat and conservation. Stud. Nat., ser. A 33: 133-166. (in Polish with English summary)

PIĘKOŚ-MIRKOWA H., KACZMARCZYK D. 1990b. Astragalus penduliflorus Lam. - ecology, threat and conservation. Stud. Nat., ser. A 33: 167-199. (in Polish with English summary)

PIĘKOŚ-MIRKOWA H., MIREK Z., MIECHÓWKA A. 1996. Endemic vascular plants in the Polish Tatra Mountains - distribution an ecology. Pol. Bot. Stud. 12: 1-107.

READ D.J., HASELWANDTER K. 1981. Observations on the mycorrhizal status of some alpine plant communities. N. Phytol. 88: 341-352.

SMITH S.E., READ D.J. 1997. Mycorrhizal symbiosis. Academic Press, London.

SMITH F.A., SMITH S.E. 1997. Structural diversity in (vesicular) - arbuscular mycorrhizal symbioses. N. Phytol. 137: 373-388.

THIPPAYARUGS S., BANSAL M., ABBOTT L.K. 1999. Morphology and infectivity of fine endophyte in mediterranean environment. Mycol. Res. 103: 1369-1379.

TROUVELOT A., KOUGH J.L., GIANINAZZI-PEARSON V. 1986. Mesure du taux de mycorhization VA d'un systeme radiculaire. Recherche de methodes d'estimation ayant une signification fonctionnelle. In: Physiological and genetical aspects of mycorrhizae. Gianinazzi-Pearson V., Gianinazzi S. (eds). INRA, Paris, pp. 217-221; http://www.dijon.inra.fr/bbceipm/Mychintec/Mycocalc-prg/download.html.

TURNAU K., HASELWANDTER K. 2002. Arbuscular mycorrhizal fungi, an essential component of soil microflora in ecosystem restoration. In: Mycorrhizal technology in agriculture. From genes to mycorrhiza application. Gianinazzi S., Schüepp H., Barea J.M., Haselwandter K. (eds). Birkhauser Verlag/Switzerland, pp. 137-149.

TURNAU K., JURKIEWICZ A., LINGUA G., BAREA J.M., GIANINAZZI-PEARSON V. 2006. Role of arbuscular mycorrhiza and associated microorganisms in phytoremediation of heavy metal-polluted sites. In: Trace elements in the environment. Biogeochemistry, biotechnology, and bioremediation. Prasad M.N.V., Sajwan K.S., Naidu R. (eds). CRC Taylor \& Francis, Boca Raton, London, New York, pp. 235-252. 
VESTBERG M., CASSELLS A.C., SCHUBERT A., CORDIER C., GIANINAZZI S. 2002. Arbuscular mycorrhizal fungi and micropropagation of high value crops. In: Mycorrhizal techno$\operatorname{logy}$ in agriculture. From genes to mycorrhiza application. Gianinazzi S., Schüepp H., Barea J.M., Haselwandter K. (eds). Birkhauser Verlag/Switzerland, pp. 223-233.
YAMATO M. 2004. Morphological types of arbuscular mycorrhizal fungi in roots of weeds on vacant land. Mycorrhiza 14: 127-131.

ZUBEK SZ., TURNAU K., BŁASZKOWSKI J. 2005. Arbuscular mycorrhiza of plants from the Mountain Botanical Garden of the Polish Academy of Sciences in Zakopane. Acta Mycol. 40 (1): $25-41$. 